\title{
Gender Involvement in Contemporary Economic Activities of Manide Tribe in Jose Panganiban, Camarines Norte, Philippines: Basis for Capacity Development Program
}

\author{
Maria Cristina C. Azuelo1, Ma. Reina A. Mabeza ${ }^{1}$ \\ ${ }^{1}$ Camarines Norte State College, Philippines
}

\begin{abstract}
This descriptive quantitative research study was conducted to determine the gender involvement in the Manide Tribe's contemporary economic activities and formulate a capacity development program for Mamanide people to acquire knowledge and uplift their economic condition. Findings reveal that the 53 Mamanide respondents, obtained by complete enumeration, are involved in contemporary economic activities like the external labor market for males and the sale of agricultural products for females. The majority of females are involved in saving and storing compared to males. Both respondents are interested in buying basic needs and producing crops and farm products. Their very high level of gender involvement has been accounted for in the external labor market, spending, and production; however, in saving and storing, the male has no involvement while the female has a high level of involvement. As to the contributing factors, the social, economic, environmental, and political factors have a very high contribution to the changes in their economic systems. The study identified areas that need to be addressed through the formulation and implementation of the Capacity Development Program.
\end{abstract}

Keywords: Capacity Development Program; contemporary; economic activities; gender involvement; Ma(ma)nide.

This is an open access article under the CC-BY-NC license.

\section{INTRODUCTION}

Economists categorized all human activities into two broad categories; economic activities and non-economic activities. As a general rule, all the activities that people do to earn a living are economic activities. The reason why practicing those activities is for an individual's self-interest. In exchange for conducting such tasks, people can gauge what returns they can receive. Therefore, if an activity is a means of livelihood for a person and produces some income for that person, then economic activity produces revenue and implies an aspect of the production process. It is important to note that it is still a productive operation, even though the output is for self-consumption; thus, an economic activity since it still contributes to the market's total supply. (Toppr, n.d.).

Therefore, economic practices are not limited to the prevailing culture or gender or sexual subjectivity since household economies are anchoring places that define individual basic ways of life. The oppressed cluster of society, commonly known as Manide, or more specifically the indigenous peoples, is not an exception to this mainstream approach, as either individual or community economic growth is rooted in an individual's unfulfilled material needs and desires.

Corresponding author

Maria Cristina C. Azuelo, tazuelo@yahoo.com; Ma. Reina A. Mabeza, tinyrein1409@gmail.com DOI: (to be assigned soon) 
Journal of Social Entrepreneurship Theory and Practice (JSETP), Vol. 1 (1), 51-67

Gender Involvement in Contemporary Economic Activities of Manide Tribe in Jose Panganiban, Camarines Norte, Philippines: Basis for Capacity Development Program

Maria Cristina C. Azuelo, Ma. Reina A. Mabeza

Locally, Manide is indigenous people known mainly by the lowlander as Kabihug. However, the tribe preferred to call themselves Manide or Mamanide because it is very personal to them. Mamanide are found at the highlands of Jose Panganiban, Camarines Norte, Philippines, and living in their permanent settlement as the government awarded almost 22 hectares of land as an ancestral domain. According to Nolasco (2015), the Manide tribe is the region's oldest surviving indigenous people. Before the emerging changes, the economic lives of the Mamanide mostly depends on the traditional form of economic activities of hunting and foraging. Forest products and seawater harvests are the common sources of their income. However, many changes have occurred in every society with the advancement of technology and globalization. Mamanide is not exempted from this transition. This sector of society started embracing the contemporary economy to endure their living condition.

Hence, strengthening economic involvement is a significant challenge for this sector of society, especially today. Everyone lives in an economy where there is an unbalanced distribution of the nation's wealth, where the poor become poorer, and the rich become richer. The unbalanced distribution of wealth within the society, the disparity among non-indigenous peoples in terms of allocation of opportunities and resources, the inadequate access to government benefits and services, as well as the issues on gender equalities and continuing marginalization and deprivation are challenges that Manide peoples are constantly struggling in their lives.

However, despite their disadvantaged situation, Mamanide is trying to find ways to look for sustainable sources of living, even if it will mean a sedentary detachment from their customary way of life. They need to find their place in economic activities and foster gender-assertive characteristics that would lift them from poverty and bring them into a more empowered community. The inclusion of Manide peoples to the contemporary economy and gender involvement in assimilating to formal commerce encourage new knowledge.

With this scenario, the researchers conducted this descriptive quantitative study to determine the gender involvement in contemporary economic activities of the Manide tribe in Jose Panganiban, Camarines Norte, Philippines, as the basis for the capacity development program.

\section{Objectives of the Study}

This study aims are to determine the Mamanide's gender involvement and the level and contributory factors of their involvement in the contemporary economic activities with the formulation of the Capacity Development Program (CAPDEP) as the study's output.

\section{RESEARCH METHOD}

A theoretical inquiry was carried out using Jon's Altman Hybrid Economic Model, which was established in 2001 to provide an extensive description of the economic activities of the Mamanide tribe. Sanders (2016) explain it represented the economy as having three sectors; the public (the State), the non-market (or customary), and the private (or market). An essential characteristic of the model was the articulations (or inter-linkages) between these sectors and recognizing the existence and inter-dependencies among the diverse and distinctive kinds of economic activity undertaken by indigenous people.

It shows the connection and interlinkages of different aspects of the Manide's economic life, from Manide's sedentary detachment in their traditional ways of living like hunting and foraging 
Journal of Social Entrepreneurship Theory and Practice (JSETP), Vol. 1 (1), 51-67

Gender Involvement in Contemporary Economic Activities of Manide Tribe in Jose Panganiban, Camarines

Norte, Philippines: Basis for Capacity Development Program

Maria Cristina C. Azuelo, Ma. Reina A. Mabeza

into the contemporary market's gradual assimilation. The primitive subsistence-based-economic activities and the inclination to swidden agriculture to generate subsistence income are slowly articulated by indigenous peoples to market or modern economy. Today, indigenous peoples' economic activities like the production of local goods and other forms of economic survival yielded within the community are not purely intended for homegrown consumption. It became the trade subject to generate adequate monetary or cash income to spend on their food and other necessities. Further, the involvement through wages earned or the supply of direct income in social security payment from several jobs is an effective means of livelihood.

Moreover, according to Peterson (2016), the principal source of cash income in the hybrid economy has always been dependent on the population's structure and composition, the desire for better accommodation, social security, and a broader range of social services. Life comfort and safety was the central tenet of the Manide peoples. In an economic clash between culture and living (life) insufficiencies, economic development can be achieved via mainstreaming or involvement in the modern-day economy that may be influenced by several factors like social, economic, environmental, and political factors by the dominant society.

Additionally, the presence of the State is vital in strengthening the Manide people's economic life. As a vulnerable component of the society, the State has to protect them from the possible exploitation, abuse, or subjugation from the dominant economy. Further, the government should promote economic and environmental programs to support this sector's plight in alleviating them from the sludge of poverty and preserving their culture.

Therefore, activities to sustain the needs of every Mamanide are not limited or concentrated to a specific role of men and women; instead, it is economic freedom and considered the right of every individual. Thus, they need to understand better what economic activities constitute in their lives before fully integrating themselves in the context of the contemporary economy.

\section{Research Duration}

The study was conducted last 2019 in the re-settlement area of Manide Tribe in Jose Panganiban, Camarines Norte, Philippines. Participants were from the Manide or indigenous peoples' population with direct participation in the contemporary economic activities.

\section{Research Design and Sampling Techniques}

A descriptive quantitative research design was used to identify the economic activities of Mamanide with the assistance of the personnel from NCIP-Daet. In obtaining the 53 respondents consisting of 24 males and 29 females, Manide husband and wife, complete enumeration was used.

\section{Data Gathering Procedure and Analysis}

Data gathering is through a personal interview using a researcher-made-surveyquestionnaire to the male and female Mamanide. It was under the IKSP, and Customary Laws Research and Documentation, and the permission is given by the Regional Director of the National Commission for Indigenous Peoples (NCIP) Regional Office V to the researchers. The Mamanide executed individual free, prior informed consent (FPIC) form as part of the ethical research consideration. Thus, National Commission for Indigenous Peoples Regional Office V issued the 
Certification of Precondition stipulating the Manide community's approval for the study's conduct within their Ancestral Domain.

Mamanide's information provided in the focus group discussion has substantiated the interpreted survey responses. In identifying their economic activities, it utilized percentage and frequency distribution. Simultaneously, the Likert scale and the average weighted mean were employed to determine gender involvement and the contributory factors.

\section{FINDINGS AND DISCUSSION}

This part presents the discussion and analysis of the Mamanide's gender involvement, level, and contributing factors in contemporary economic activities.

\section{Contemporary Economic Activities of Manide Peoples in Terms of Revenue Generation, Spending Saving and Storing, and Production}

This portion presents the Manide people's involvement in different contemporary economic activities like revenue generation, spending, saving and storing, and production employing frequency and percentage distribution.

Contemporary economic activities of Manide Tribe. Table 1 shows the different involvement of Manide in economic activities. It reflects that for males, generating revenue or income for their families was centered on the external labor market while females lie on the sales of farm or agricultural products. Both respondents prioritized buying basic needs like foods, clothing, and other household necessities in terms of spending. Although they are both aware of the importance of savings, results show that females' manifested their higher inclination in this economic activity compared to male Manide. Concerning production activity, both were concentrated on producing agricultural products.

Table 1. Contemporary Economic Activities of Manide Tribe

\begin{tabular}{|c|c|c|c|c|}
\hline Economic Activities & Male & $\%$ & Female & $\%$ \\
\hline 1. Revenue generation & $\begin{array}{l}\text { External labor } \\
\text { market }\end{array}$ & 100 & $\begin{array}{l}\text { Sales of farm } \\
\text { products }\end{array}$ & 83 \\
\hline 2. Spending & Buying basic need & 100 & Buying basic need & 100 \\
\hline 3. Saving and storing & $\begin{array}{l}\text { Cash saving in a } \\
\text { piggy bank }\end{array}$ & 38 & $\begin{array}{l}\text { Cash saving in a } \\
\text { piggy bank }\end{array}$ & 72 \\
\hline 4. Production & $\begin{array}{l}\text { Production of } \\
\text { agricultural } \\
\text { products }\end{array}$ & 96 & $\begin{array}{l}\text { Production of } \\
\text { agricultural } \\
\text { products }\end{array}$ & 55 \\
\hline
\end{tabular}

The study implies that the Manide has no longer limited to traditional subsistence economic activities like hunting and foraging. In particular, males possessed a liberal mind in seeking economic activities outside the tribe and assimilating in the current economic labor market.

As one respondent, who happened to be a Para-Teacher, affirmed that "Matagal ng nag-titiis ang aming tribu sa kahirapan, dahil sa takot ng aming mga magulang na kami ay kutyain at maliitin ng mga tagalog dahil sa kawalan namin ng sapat na kaalaman ay mga dahilan kung bakit naaranasan naming ang kahirapan. Subalit nagbabago ang panahon, kahit papaano ay 
Journal of Social Entrepreneurship Theory and Practice (JSETP), Vol. 1 (1), 51-67

Gender Involvement in Contemporary Economic Activities of Manide Tribe in Jose Panganiban, Camarines

Norte, Philippines: Basis for Capacity Development Program

Maria Cristina C. Azuelo, Ma. Reina A. Mabeza

nagkakaroon na kami ng pag-babago. Ang kakulangan sa mga nakukuhang produkto mula sa mga likas na yaman at kompetisyon sa mga tagalog o unat sa mga likas na yamang ito, ay mga dahilan upang aming yakapin ang makabagong uri ng hanap-buhay. Mahirap ang ganitong sitwasyon para sa mga katulad namin, subalit kailangan naming gawin para na rin sa kapakanan ng aming mga pamilya." (It is a long battle for Manide people to live in the shadow of poverty, the fear of being oppressed by the lowland population and lack of knowledge is the reason why we endure economic disadvantage. However, the situation has changed progressively. The limited resources and the competition among the lowlanders from the forest produce as a means of livelihood are reasons, we started embracing a new economic activity. We knew the situation is difficult for us, but we have to bear it for the sake of our family.)

According to Fui (2003), this concept implies that indigenous peoples' communities adapted to changes, looking for sustainable economic activities even if it would mean sedentary detachment from their traditional way of life.

Manide peoples also give the highest consideration in their spending activities. Regardless of gender type, the primary objective is to provide for the basic needs of their families. It was clearly asserted of Nanay Rosie, one of the female Manide which says, "Ang pag-kain ang nagbibigay sa atin ng buhay at kalakasan, ito ang dahilan kung bakit ang bawat tao ay nag-hahanap-buhay." (Food is life. The reason why people work is to sustain the need for food, it is the reality, it is the motivating factor for everyone why we have to engage in work).

STEM learning (2016) emphasized that food security is an essential matter for Manide's life, and this exists when people have physical and economic access to sufficient, safe, and nutritious food.

Moreover, for females, savings is also an important economic activity that, even a little money, they have tried to save to have something to use during an urgent situation. However, they did not keep their money inside their house to avoid the possibility or risk of losing and to prevent their family members from taking the money and used it to buy liquor. It proves that even indigenous peoples in general progressively assimilated in economic or fiscal methods. Arnado (2012) point out that IPs continue to maintain and elaborate a gendered system of informal storing of money; thus, it is a crossing point of tradition and modernity.

The production activities of Mamanide centered on producing crops like planting palay and different varieties of vegetables and fruits. For Mamanide, taking part in agricultural farming is important because it helps enhance food security, maintain biodiversity, and protect their natural resources.

As one male manide take part on this activity and point out "Ang pag-tatanim ay bahagi na ng buhay naming mga Manide, sa pamamagitan ng pag-tatanim, natutulungan naming maibalik ang kalikasan at maging maganda ulit sa lahat, hinde lamang sa mga tao, kung hinde pati sa ibang uri ng nilalang na uma-asa dito". (Planting is part of the Mamanide people's life. Through planting, we were able to help our environment recover and become vibrant again, not only for us but also for other species found in the ecosystem."

Foodtank (2017) emphasized that indigenous peoples have provided a series of environmental and cultural services to humankind by playing a crucial role in sustainable smallholder farming worldwide. 


\section{Level of IPs' Gender Involvement in Contemporary Economic Activities in Terms of Revenue, Generation, Spending, Saving and Storing, and Production}

This section expounds on the level of gender involvement in the different contemporary economic activities using a three-point Likert scale and a Weighted mean in analyzing the data gathered to wit;

Legend:

2.34 - 3.00 Very High Involvement (VHI)

1.67 - 2.33 High Involvement (HI)

1.00 - 1.66 Non- Involvement (NI)

\section{Revenue Generation}

Table 2 presents the level of gender involvement of Mamanide in different economic activities for revenue generation. Generally, data show that the indigenous peoples' economic activities with very high involvement include the external labor market, small scale mining, farm, and other agricultural products with a weighted mean of $2.57,2.50$, and 2.37. On the other side, the economic activities that indigenous peoples have no involvement in include water and other seafood products, forest sales and other hunted animals with a weighted mean of 1.57 and 1.09 , respectively.

Table 2. Level of Gender Involvement of Mamanide in Revenue Generation

\begin{tabular}{|c|c|c|c|c|c|c|}
\hline \multirow{2}{*}{ Indicators } & \multicolumn{2}{|c|}{ Male } & \multicolumn{2}{|c|}{ Female } & \multirow{2}{*}{ Total } & \multirow{2}{*}{$\begin{array}{l}\text { Adjectival } \\
\text { Rating }\end{array}$} \\
\hline & WM & $\mathrm{A} / \mathrm{R}$ & WM & $\mathrm{A} / \mathrm{R}$ & & \\
\hline 1. External labor market & 3.00 & VHI & 2.14 & HI & 2.57 & VHI \\
\hline $\begin{array}{l}\text { 2. Wage labor inside } \\
\text { community }\end{array}$ & 2.00 & $\mathrm{HI}$ & 2.14 & HI & 2.07 & $\mathrm{HI}$ \\
\hline $\begin{array}{l}\text { 3. Sales of forest and other } \\
\text { hunted animals }\end{array}$ & 1.17 & $\mathrm{NI}$ & 1.00 & $\mathrm{NI}$ & 1.09 & $\mathrm{NI}$ \\
\hline $\begin{array}{l}\text { 4. Sales of water and other } \\
\text { seafood products }\end{array}$ & 1.52 & $\mathrm{NI}$ & 1.59 & NI & 1.57 & $\mathrm{NI}$ \\
\hline $\begin{array}{l}\text { 5. Sales of farm/ } \\
\text { agricultural products }\end{array}$ & 2.21 & $\mathrm{HI}$ & 2.52 & VHI & 2.37 & VHI \\
\hline $\begin{array}{l}\text { 6. Others (small scale } \\
\text { mining) }\end{array}$ & 2.50 & VHI & 2.50 & VHI & 2.50 & VHI \\
\hline Average Weighted Mean & 2.07 & $\mathrm{HI}$ & 1.98 & HI & 2.03 & $\mathrm{HI}$ \\
\hline
\end{tabular}

In general, it shows that the Manide Tribe of Jose Panganiban is highly involved in revenue generation activities. Based on the results, Manide peoples are gradually placing themselves in the 
external labor market's realm to sustain the needs of their families. This situation leads them to become prone or vulnerable to discrimination, one of the male manide shared his experience "Mahirap para sa katulad namin na mga Manide ang tanggapin ng mga unat bilang trabahador, nakakaranas kami na pag-tawanan, ngunit kailangan na maging matatag, alam naman namin ang sitwasyon. Nagpapasalamat kami sa ilang mga tagalog/unat na binigyan kami ng pag-kakataon na maka-pagtrabaho sa kanila. Wala naman kaming pili, basta legal na trabaho, tatanggapin yan, ang importante ay kumita kami, makabili ng pangangailangan ng aming pamilya lalo higit ay pag-kain." (Finding a job is difficult for us, at first, some people laugh at us, but we have to carry on, we knew our situation, and we are thankful that many of the lowlanders give us a chance to work with them. For us, male, whatever kind of job as long as it is legal, we will accept that, what important is we earned for our living, we have something to bring in to our families, especially food for our table).

Additionally, another respondent further disclose "Yun Barangay kinuha kami na barangay health worker at paralinig rin. Katulad ni Ate Caring, kinuha siya ng Osmena Elementary School para maging taga-paglinis. Natatakot kami nug una tapos nahihiya rin, pero dahil mabuti naman ang pakikitungo sa amin, unti-unti nawala yun aming hiya, nararamdamn naming na tanggap naman kami na ng mga unat/tagalog." (Our Barangay hired some of us here as Barangay utility/health workers. Like Ate Caring, she worked at Osmena Elementary School as a janitress/utility worker. At first, we are shy and afraid; however, we adapt the situation little by little because of the good treatment we receive from Tagalog (pertains to lowlander). It is a big thing for us because we felt that society started accepting us.)

On the other hand, the limited involvement in economic activities on forest and other hunted animals' sales was affected by the strict implementation of the government laws and regulations prohibiting the hunting of wild animals and gathering of other forest species. It was explained by the tribe elder as he pointed out "Limitado ang galaw namin sa pag-hahanap ng mapapag-kakitaan sa gubat, kailangan sumunod sa batas, ipinag-ba-bawal na ang pang-huhuli ng mga ligaw na hayop at maging ng mga halaman gubat. Halimbawa, kung kami ay manghuhuli ng hayop dapat ito ay para sa pansariling pag-kain at hinde dapat na ipinag-bibili. Ito rin ang dahilan ng mga ibang kalalakihan ng tribu upang mag-hanap ng hanap-buhay sa labas ng tribu." (We need to follow the laws of our government, although there is provision on the law that grant us to exercise our culture, getting forest products and engaging in flora and fauna is prohibited and, in some instances, it should only be for our consumption and not be subject for trading or sale. This is also the reason why most of our men here are trying to secure a job in the dominant society).

Although legislation and frameworks are in place, according to Torres (2016), issues on indigenous peoples' rights are yet to be resolved, including their right to economic inclusion. Thus the stated situation further established a common desire for the Manide peoples to participate actively in economic life outside their community.

\section{Spending}

Table 3 presents the gender involvement of Manide in spending activities. It reflects that both male and female indigenous peoples are very highly involved in buying basic needs with a weighted mean of 3.00 and 2.93. The male indigenous also have very high involvement in paying monthly amortization or dues for their motorcycles with a weighted mean of 3.00 . 
However, it is significant to note the non-involvement of both male and female Manide to the economic activity registered a total weighted mean of 1.44 , which includes purchasing materials for home improvement or house repair with a weighted mean of 1.38 and 1.50, respectively.

Table 3. Level of Gender Involvement of Manide in Spending

\begin{tabular}{|c|c|c|c|c|c|c|}
\hline \multirow{2}{*}{ Indicators } & \multicolumn{2}{|c|}{ Male } & \multicolumn{2}{|c|}{ Female } & \multicolumn{2}{|l|}{ Total } \\
\hline & WM & $\mathrm{A} / \mathrm{R}$ & WM & $\mathrm{A} / \mathrm{R}$ & WM & $\mathrm{A} / \mathrm{R}$ \\
\hline $\begin{array}{l}\text { 1.Buying of basic needs } \\
\text { (foods, clothing, } \\
\text { household needs }\end{array}$ & 3.00 & VHI & 2.93 & VHI & 2.97 & VHI \\
\hline 2. Purchase of medicine & 1.46 & NI & 1.72 & HI & 1.59 & NI \\
\hline $\begin{array}{l}\text { 3. Purchase of materials } \\
\text { for home improvement } \\
\text { or house repair }\end{array}$ & 1.38 & NI & 1.50 & NI & 1.44 & NI \\
\hline $\begin{array}{l}\text { 4. Purchase of school } \\
\text { supplies }\end{array}$ & 1.54 & NI & 1.83 & HI & 1.69 & $\mathrm{HI}$ \\
\hline 5. Transportation & 1.79 & HI & 1.64 & NI & 1.72 & $\mathrm{HI}$ \\
\hline $\begin{array}{l}\text { 6. Other, specify, } \\
\text { payment of monthly } \\
\text { dues for motorcycles }\end{array}$ & 3.00 & VHI & 2.00 & $\mathrm{HI}$ & 2.50 & VHI \\
\hline Average Weighted Mean & 1.83 & $\mathrm{HI}$ & 1.74 & $\mathrm{HI}$ & 1.98 & $\mathrm{HI}$ \\
\hline
\end{tabular}

The result provides an overview of Manide's present-day conceptual perception in their level of gender involvement in economic activities in terms of spending. It implies that Manide people prioritize spending, which focused on purchasing and securing basic needs for their families, particularly food for the table.

In the interview with a female respondent, she emphasized that "Ang pangunahing pinag-lalaanan namin ng pera ay ang pag-bili ng mga pangangailangan sa bahay, lalo na ng bigas, ganun din pinag-lalaanan rin ang baon ng mga bata sa pag-papasok sa eskwela. Kung halinbawa na may matira, itinatago yun para kahit papano meron nakahanda sa mga dagliang panganga-ilangan." (Our priority is the purchase of the family's necessities; we allot the money we have to buy foods and secure the school allowances of our children. If there is money left, we save it for the future).

Segal (2019) notes that with minimal income, the indigenous peoples are in the daily race to meet their most basic and modest survival needs.

In some economic activities, the involvement of male Manide is not imminent, as compared to females. A male respondent make clear that in some situation, they have to spend money on their own need as such; "Oo, bumibili kami ng alak, upang maki-pagsaya sa ibang kasama lalo na 
kung sa araw naman ng aming pamamahinga. Yung iba naman, nagbabayad sila para sa buwanang hulog ng kanilang motorsiklo." (Yes, we spend money to buy liquor, to drink with other Mamanide, especially during those days that we are off from our work. For other male Manide, they spend their money to pay for their motor loan amortization).

It denotes that these people have different priorities or distinct patterns when it comes to spending; what male Manide values might not be the same as what female values. Further, it also mentioned that men and women have different gender roles and responsibilities (United Nations, 2016), and for these reasons, they also often have different needs, desires, and interests.

\section{Saving and Storing}

Table 4 presents the level of gender involvement in the economic activities of Manide about saving or storing. It depicts the non-involvement of male Manide in all identified economic activities concerning saving and storing, having a weighted mean of 1.34. On the other hand, female indigenous reflected a very high involvement in saving and storing activities, including the traditional way of saving or storing in some parts of their clothes with a weighted mean of 3.00. Another way of saving or storing money as practiced by female Manide is through a piggy bank with a weighted mean of 2.34 .

Table 4. Level of IP's Gender Involvement in Saving and Storing

\begin{tabular}{|c|c|c|c|c|c|c|}
\hline \multirow{2}{*}{ Indicators } & \multicolumn{2}{|c|}{ Male } & \multicolumn{2}{|c|}{ Female } & \multirow{2}{*}{$\begin{array}{l}\text { Total } \\
\text { WM }\end{array}$} & \multirow{2}{*}{$\begin{array}{l}\text { Adjectival } \\
\text { Rating }\end{array}$} \\
\hline & WM & $\mathrm{A} / \mathrm{R}$ & WM & $\mathrm{A} / \mathrm{R}$ & & \\
\hline $\begin{array}{l}\text { 1. Cash savings or storing in a } \\
\text { piggy bank }\end{array}$ & 1.38 & NI & 2.34 & VHI & 1.86 & $\mathrm{HI}$ \\
\hline $\begin{array}{l}\text { 2. Savings or storing in different } \\
\text { places of house }\end{array}$ & 1.00 & NI & 1.07 & NI & 1.04 & NI \\
\hline 3. Investment in properties & 1.25 & NI & 1.21 & NI & 1.23 & NI \\
\hline 4. Investment in livestock & 1.13 & $\mathrm{NI}$ & 1.55 & NI & 1.34 & NI \\
\hline 5. Bank savings & 1.00 & NI & 1.00 & $\mathrm{NI}$ & 1.00 & $\mathrm{NI}$ \\
\hline $\begin{array}{l}\text { 6. Others (small knitted "takupis" } \\
\text { and parts of women clothes) }\end{array}$ & 2.33 & HI & 3.00 & VHI & 2.67 & VHI \\
\hline Average Weighted Mean & 1.34 & NI & 1.57 & NI & 1.52 & NI \\
\hline
\end{tabular}

Results imply that if Manide peoples can save or store some of their earnings, they do it traditionally, or through knowledge system practices like placing it in takupis for male and female, putting the money in some parts of their clothes, a storage place.

Female Manide tends to store for a short-term duration as they address the immediate needs of the family. An elder female stress out " Alam namin ang kahalagahan ng pag-susubi, subalit kailngan unahin ang mga kailangan ng pamilya bago makapag-tabi ng pera, kung sakali naman na meron 
matira pagka-tapos bilhin ang mga kailangan, tinatago namin ang pera sa aming damit, kapag sa loob ng bahay, nakukuha minsan ng miyembro din ng pamilya, ang problema pinapambili lang naman ng alak." (We are aware of the importance of savings; however, it is difficult for us to strictly undertake it because of our limited financial resources if, for instance, there is a surplus, I always keep it, I knitted it on my dress so that nobody can get it, sometimes the male member of our household get the money without informing us and use only to buy liquor).

In contrast male respondent further illuminates: " Hinde namin prayoredad ang pag-i-impok, gawain yun ng aming mga asawa, lahat naman ng aming kita sa araw-araw ay ibinibigay naman sa kanila, para ding kayong mga Tagalog. Pero minsan kung kumita kami ng malaki-laki, kumukuha rin kami ng di na nag-papa-alam, tinatago naming sa takupis para pambili ng alak o minsan ay pagsabong" (Savings is not our priority because we give all the money we earned to our wife to finance the needs of the family, the same practice of the Tagalog people like you, but sometimes if we earned considerable amount, we slash a little from it secretly and placing the money in our takupis to buy liquor or sometimes to spend on cockfighting).

The results affirm Arnado's findings that in this particular economic activity, it explains that gender shapes practices on informal storing of cash, particularly in terms of duration, location, and purpose of savings and storing. Thus, in this sense, it defines the Mamanide's gender differences in perception about saving and storing patterns as it arises from male and female's varying comfort zones, frequency of spending, and amount of money stored.

\section{Production}

Table 5 reflects the Mamanide level of gender involvement in economic activities about production. Records show that both male and female indigenous had a very high involvement in economic activities in terms of production of crops and other farm products with a weighted mean of 2.83 and 2.86, respectively, or a total weighted mean of 2.85 .

It is noteworthy to observe that both male and female Manide have no involvement in all different production activities. They do not engage in forest-based output production like culturing honeybees, producing forest-based materials for making or weaving handicrafts, and producing nurturing wild forest flowers intended for sale with a corresponding total weighted mean of 1.08, 1.02 , and 1.62 .

Table 5. Level of Manide's Gender Involvement in Production

\begin{tabular}{cccccccc}
\hline \multicolumn{1}{c}{ Indicators } & \multicolumn{2}{c}{ Male } & \multicolumn{2}{c}{ Female } & Total & Adjectival \\
& WM & AR & WM & AR & WM & Rating \\
\hline $\begin{array}{c}\text { 1. Production of agricultural } \\
\text { crops and other farm products }\end{array}$ & 2.83 & VHI & 2.86 & VHI & 2.85 & VHI \\
$\begin{array}{c}\text { 2. Production of domestic } \\
\text { animals intended for sale }\end{array}$ & 1.75 & HI & 1.59 & NI & 1.67 & HI \\
$\begin{array}{l}\text { 3. Production of forest-based } \\
\text { 60 }\end{array}$ & 1.04 & NI & 1.11 & NI & 1.08 & NI \\
\hline
\end{tabular}


Journal of Social Entrepreneurship Theory and Practice (JSETP), Vol. 1 (1), 51-67

Gender Involvement in Contemporary Economic Activities of Manide Tribe in Jose Panganiban, Camarines

Norte, Philippines: Basis for Capacity Development Program

Maria Cristina C. Azuelo, Ma. Reina A. Mabeza

output like culturing honey-bees

4. Production of forest-based

1.00

$\mathrm{NI}$

1.03

NI

1.02

NI

materials for making or weaving handicrafts

5. Production of nurturing wild forest flowers intended for sale

The study's result implicitly explained the involvement in the production activities of male and female Manide, which mainly centered on producing crops and other farm products. The results imply that both male and female indigenous are very highly involved in this particular economic activity.

However, it is noted that female Manide have high involvement, as the respondent expound "Para sa aming mga kababaihan, parang libangan na namin ang pagtatanim, ginagawa namin yan kapag-tapos na ang mga gawain sa bahay. Madalas mga gulay o yung madaling ma-ani ang aming itinatanim, kaya lang kapag nag-aani na kami ang ibang mga taga baba, binarat ang tinda namin." (For us, women's engagement in farming is a leisure activity since we are often left in the house, so after doing household chores, we spend our time farming. Mostly we planted crops that are easily yielded, like different varieties of vegetables and root crops; what makes us frustrated is when harvesting time comes, and we sell our produce. Some lowlanders wanted to buy it at a low price (binabarat kami ng bumibili). Our husband helps us in farming only when they did not have work from outside the tribe or during their worked-off).

This situation is linked to the idea of Abass (2018), showing that women account for nearly half of the world's smallholder farmers and produce 70 percent of the world's food. On the other side, they cannot neglect the male indigenous involvement in growing crops and other farm products. Besides engaging in economic activities outside the tribe, they still manage to have very high involvement in this economic activity; hence, gender relations and division of work in the community are well defined.

Production of forest-based material for making or weaving handicrafts is the least economic activity of male and female Manide. Because the community population comprises young people, the level of interest in this kind of work is low because most of them tend to look for a job outside the tribe. Moreover, for Manide people, handicraft is not a promising source of income since it is difficult to find a regular market for their products, and it takes time for them to sell their produce.

\section{Contributory Factors on Gender Involvement of Mamanide in Contemporary Economic activities along with Social, Economic, Environmental and Political Factors}

This part explains why Mamanide started assimilating contemporary economic activities and sedentary, leaving the traditional way of their economic life. The Likert scale, weighted mean, and the equivalent adjectival rating were used to interpret and analyze the results.

Table 6 deliberates the significant contributory factors of Mamanide in their involvement in contemporary economic activities. To account, it involves social, economic, environmental, and 61 
political factors. Generally, all identified factors have a very high contribution to the Mamanide's gender involvement in contemporary economic activities.

Table 6. Contributory Factors of Involvement in Contemporary Economic Activities

\begin{tabular}{ccccccc}
\hline Contributory Factors & \multicolumn{2}{c}{ MALE } & \multicolumn{2}{c}{ FEMALE } & \multicolumn{2}{c}{ TOTAL } \\
& WM & A/R & WM & A/R & & \\
\hline Social Factor & 3.00 & VHC & 2.93 & VHC & 2.97 & VHC \\
Economic Factors & 3.00 & VHC & 3.00 & VHC & 3.00 & VHC \\
$\begin{array}{c}\text { Environmental } \\
\text { Factors }\end{array}$ & 2.88 & VHC & 2.90 & VHC & 2.89 & VHC \\
$\begin{array}{c}\text { Political Factors } \\
\text { S }\end{array}$ & 3.00 & VHC & 3.00 & VHC & 3.00 & VHC \\
\hline
\end{tabular}

Legend: VHC = Very High Contribution

In social factors, getting into good jobs or finding a better source of employment has a high contribution to the involvement of Mamanide in economic activities. This result can be associated with their desire to liberate themselves from the sphere of poverty gradually. Getting a good job is equivalent to the lives of both male and female Manide as it has a domino effect in their current economic life.

During the course of discussion one male respondent highlighted "Para sa amin ang pagkaka-roon ng maayos at palagiang hanap-buhay ay mahalaga, kung meron kami nito, pwede kaming makapag-patayo ng maayos na tahanan, maka-pag-aral ng tuloy-tuloy ang aming mga anak, at higit sa lahat ang maseguro ang pagkakaroon ng pag-kain ng aming mga pamilya. Importante sa amin ang hanap-buhay na maayos, masaya at kontento kami kung mag-kakaroon ng regular na hanapbuhay." (We usually perceived that by acquiring a constant source of income, we would be able to construct or build houses, have an opportunity to send our children in school, and, most of all, always have enough food for the table. Only these things are important to us; this makes us happy and contented).

Accordingly, life is not meaningful except in the impact it has on other's lives. Social development affects individuals' economic opportunities; it aims to create better economic opportunities for the Manide population. Thus, the involvement of indigenous peoples in social development is a crucial pillar of sustainable economic growth.

Meanwhile, the findings deeply elucidate that the contributory economic factors on gender involvement of both male and female Manide involve having a regular income source and an increase in the purchasing power, resulting in the escalation of their living conditions. Having a regular source of income gives one the ability to command others' labor. Hence, to some extent, purchasing power is power over other people, to the point that people are willing to trade their labor or goods for money or currency (("Purchasing power and the Consumer Price Index (CPI)", 2018)). 
Journal of Social Entrepreneurship Theory and Practice (JSETP), Vol. 1 (1), 51-67

Gender Involvement in Contemporary Economic Activities of Manide Tribe in Jose Panganiban, Camarines Norte, Philippines: Basis for Capacity Development Program

Maria Cristina C. Azuelo, Ma. Reina A. Mabeza

It relates to what the indigenous peoples bear out, when an elder woment of the tribe stipulated " Katulad ng marami, ang gusto rin naming mga Mamanide ay isang payapa, masaya at kontentong pamumuhay at ang pag-kakaroon ng maayos na hanap-buhay ang isa sa aming mga naisin, simpleng buhay lang ang kailangan namin, ang sobra sa aming pangagailangan ay pwedeng mag-dulot sa amin ng isang negatibong kaisipan" (Like a common lowlander, our aspiration to is a happy and contented life, our goal is to secure a regular source of income to give our family a comfortable, decent, and restful life. This is our simple aspiration; what we want is a simple way of living, and earning beyond what we do not need is unnecessary).

The study conjoins to the government's Ambisyon Natin 2040, which represents the Filipino people's vision and aspirations for themselves and in the country in the next 25 years. The kind of life Filipinos wanted for themselves is a life that is firmly rooted, comfortable, and secure or the "matatag, maginhawa, at panatag na buhay para sa lahat" (National Economic Development Authority, 2016).

The results also impart the environmental factors that contribute to the involvement of both Manide in economic activities. In particular, one is due to the scarcity of supply from the natural resources, which in prior time serves as the main source of food for the Manide peoples in Jose Panganiban.

In an interview to a male respondent he strongly uphold " Ginagalang namin ang ating kapaligiran, para sa amin yan ay isang sagrado, ayaw namin itong maabuso, kung kaya kahit mahirap pinipilit naming maka-hanap ng ibang pag-kakakitaan na hinde ma-a-apektuhan ang aming kapaligiran. Mahalaga ito pra sa amin, nagpapatunay ito $\mathrm{ng}$ pag-galang sa aming karapatan bilang mga IPs, sa pag-bibigay sa amin ng ancestral land na ito, naramdaman namin na mahalaga kami sa lipunan. Subalit hinde nawawala na may mga grupo pa din na gustong abusuin ang aming lugar. Ngunit hinde man ito pinapayagan ngMunisipyo kaya sobra ang pasalamat naming kay Meyor". (We respected the environment, for us it is sacred, we do not want to abuse our natural resources, the reason why we look for alternative sources of income from the dominant society, even it will mean our detachment from our culture and tradition. We valued this place much, as it is the manifestation that our government valued indigenous peoples' rights by providing us this almost 22 hectares as our ancestral domain. However, we are sad because we knew some forces were really trying to use their power to exploit our environment. We are grateful that LGU Jose Panganiban did not permit these people to manipulate the situation).

The traditional food system provided by the natural environment, according to Kuhlein and Chan (2000) as cited by Elliot et al. (2012), includes all of the food species that are available for a particular culture from local natural resources and the accepted patterns of their use within that culture. As imparted by the tribe elders, the interconnectedness of natural resources in indigenous peoples' quest for food to alleviate hunger and poverty are at stake. They highlight a situation that prompted indigenous peoples to depart from their traditional lifestyle and means of living and started to embrace new economic ways of life, securing more generous access to their own basic needs, especially in terms of food networks and security.

The last contributory factors for Manide's gender involvement in contemporary economic activity is the political factors. Recognizing the rights and privileges and their representation is a very high contributory factor. 
Journal of Social Entrepreneurship Theory and Practice (JSETP), Vol. 1 (1), 51-67

Gender Involvement in Contemporary Economic Activities of Manide Tribe in Jose Panganiban, Camarines

Norte, Philippines: Basis for Capacity Development Program

Maria Cristina C. Azuelo, Ma. Reina A. Mabeza

As the group conscientiously affirmed that "Yun pag-empleyo sa mga tribe member naming ay isang patunay na sa panahong ito ay unti-unti ng kinikilala ang aming karapatan at prebilihiyo $\mathrm{ng}$ sosyedad. Masaya kami na meron naka-abot sa miyembro namin sa kolehiyo, si Ricky na ngayon ay isa ng Para-Teacher, meron din na naging empleyado ng isang mining company, ito ay mga patunay na binibigyan kami ngayon ng pag-papahalaga ng ating pamayanan, masaya kami doon dahil makakatulong ito upnag kahit papano ay maiba ang takbo ng buhay ng susunod pa naming henerasyon. Nabisita na rin ang lugar namin ni Ms Kara David, pinalabas niya sa kaniyang programa sa tv ang buhay namin, ibig sabihin noon kahit papano napapansin din kami ng lipunan, na yun ay pwede mag-bigay sa amin ng kahit papano ay kaunting ka-alwanan sa buhay." (Employing some of our tribe members in a particularly private and public entities in the nearby places is a clear manifestation of our acceptance and recognition in the mainstream society, we are proud of that, just like Ricky who happened to reach College education, and now is working as a Para-Teacher. Also, we have one member here employed in one mining company here in Panganiban; we are also thankful that Ms. Kara David featured us in her TV documentary program. This manifest that dominant society is now recognizing us, the indigenous peoples right and privileges).

This concept is consistent with Kassas (2015) ideas, which stressed the possibility for all citizens to participate in public affairs management, which is at the very heart of democracy. It is an inevitable remark that interlinks to the outcome of the current study.

\section{Capacity Development Program (CAPDEP) to Enhance Mamanide Gender Involvement in Contemporary Economic Activities}

Conclusively, Article 23 of UNDRIP (2018) upholds that indigenous people have the right to determine and develop priorities and strategies for exercising their right to development. In particular, indigenous peoples have the right to be actively involved in developing and determining health, housing, and other economic and social programs affecting them and, as far as possible, to administer such programs through their institutions.

Almost all of the Manide are involved in economic activities, either outside or within the community. Many of them pointed out that they should not place their economic activities on individual advancement. It must be relationally and holistically anchored on total community development.

On this premise, introducing the capacity development program concept for the economic empowerment of Manide peoples to the whole community is necessary to improve and capacitate their knowledge and make them economically empowered. This proposed program is based on the Mamanide views, and the study's findings focused on 1. Program on Community Development and Good Governance; 2. Livelihood and Income Generating Program; 3. Education, Knowledge Support Program, and Preservation of Indigenous Culture; and 4. Gender Equality and IPs Inclusivity to Mainstream Economy.

Mennyhart (2018) emphasizes that everyday Manide tribe seeks to expand its economic prospects through a fluid cultural framework and habitus that maintains cultural values and incorporates new practices. For Clarke (2018), the transformative change for Manide peoples would not occur without economic development that supports indigenous jurisdiction and rights. The study highlighted the economic activities of Mamanide peoples focused on the external labor market and production of agricultural crops and farm products. The main purpose is not only for 
homegrown consumption but rather for trading/selling. Like any lowland individual, Mamanide can be involved in any economic activities to endure living conditions and develop selfdetermination to seize economic opportunities to come up with a sustainable economic community for all and freedom from government dependency.

The level of involvement in male and female Manide in contemporary economic activities emphasized no restrictions on specific gender categories or men's and women's roles. Instead, it is financial freedom and considered the right of every individual to sustain their needs. These facts unveiled their openness to the concept of gender equality by valuing the significant contribution of women in their plight for economic development. Anxo (2011) shows the trends suggest that the new female gender role has increasingly incorporated in the dimensions of economic independence and support responsibilities that until quite recently belonged to the male domain and has promoted a redistribution of responsibilities for the economic provision to a family between men and women.

The openness of the dominant society on the gender participation of male and female Manide, not only in terms of economic activities but also on the social aspect of indigenous people's life, heightened the opportunity to elude the endless possibility of discrimination and marginalization amongst this sector of society. The acknowledgement of the presence of Mamanide and the recognition of their rights and privileges manifested the dominant society's acceptance of the former in the contemporary economy.

As written in The 1987 Constitution of The Republic of The Philippines - Article XIII, Social Justice and Human Rights Section 1, the Congress shall give the highest priority to enacting measures that protect and enhance the people's right to human dignity and reduce social, economic, and political inequalities. Moreover, Section 2 states that removing cultural inequities by equitably diffusing wealth and political power for the common good and promoting social justice shall include the commitment to create economic opportunities based on freedom of initiative and self-reliance.

\section{CONCLUSION}

Generally, it is a common conception that indigenous people face marginalization, exclusion, and poverty in the place where they live. It significantly views the lower standards of living and, often, feelings of dislocation and disempowerment. The males and females Manide people in Jose Panganiban are not exempt from this situation. They were suffering from poverty, scarcity, and the dropping of yields. Further, the strict implementation of government policies and regulations, particularly RA 9147, otherwise known as the Wildlife Resources Conservation and Protection Act, also affected the Manide's economic livelihood.

Indigenous people are diligent and conscientious. Although other resources are available within their community to serve as their income sources, their insufficient knowledge and lack of adequate support hampered them in doing so. Therefore, their choice to increase their living conditions is to engage in the labor market outside the tribe and integrate themselves into mainstream or contemporary economic activities. Hence, it is important to equip them with relevant skills, technological know-how, and knowledge of their fundamental rights and economic freedom. 
Journal of Social Entrepreneurship Theory and Practice (JSETP), Vol. 1 (1), 51-67

Gender Involvement in Contemporary Economic Activities of Manide Tribe in Jose Panganiban, Camarines

Norte, Philippines: Basis for Capacity Development Program

Maria Cristina C. Azuelo, Ma. Reina A. Mabeza

It is part of the growth and elimination of income poverty to close the well-being gap between males and females Manide. Greater gender equality also increases economic effectiveness and enhances other outcomes of growth. Happiness, which occurs when harmony exists between individuals, is pursued by equal cooperation between men and women or husbands and wives.

\section{ACKNOWLEDGEMENT}

The researcher wishes to thanks all the people who extended their expertise in the conduct of this study.

\section{REFERENCES}

Abass, J. (2018). Women grow 70\% of Africa's food. But have few rights over the land they tend. Retrieved from https://www.weforum.org/agenda/2018/03/women-farmers-foodproduction-land-rights/

Anxo, D., Mencarini, L., Pailhé, A., Solaz, A., Tanturri, M., \& Flood, L. (2011). Gender Differences in Time Use over the Life Course in France, Italy, Sweden, and the US. Feminist Economics, 17(3), 159-195. doi: 10.1080/13545701.2011.582822

Arnado, J.M. (2012). Hidden in a Coke Bottle: Modernity, Gender and the Informal Storing of Money in Philippine Indigenous Communities.

Clarke, A., \& author, V. (2018). Build the Indigenous economy to address poverty. Retrieved from https://policyoptions.irpp.org/magazines/September-2018/build- indigenous-economyaddress-poverty

Elliott, B., Jayatilaka, D., Brown, C., Varley, L., \& Corbett, K. (2012). "We Are Not Being Heard": Aboriginal Perspectives on Traditional Foods Access and Food Security. Journal Of Environmental And Public Health, 2012, 1-9. doi: 10.1155/2012/130945

Honoring International Day of the World's Indigenous Peoples. (2017). Retrieved from https://foodtank.com/news/2017/08/celebrating-international-day-of-the-worlds-indigenouspeoples/

Fui, L. (2003). Economic advancement and poverty eradication among the aborigines in Malaysia. Retrieved from http://www.fao.org/3/xii/0175-a2.htm

Kassa, S. (2015). Challenges and Opportunities of Women Political Participation in Ethiopia. Journal Of Global Economics, 03(04). doi: 10.4172/2375-4389.1000162

Menyhart, A. (2018). Rethinking Western perceptions of Indigenous knowledge and economy. NEW: Emerging Scholars In Australian Indigenous Studies, 50-55. doi: 10.5130/nesais.v2i1.1473

National Economic Development Authority. (2016). About AmBisyon Natin 2040 - AmBisyon Natin 2040. Retrieved from http://2040.neda.gov.ph/about-ambisyon-natin-2040

Nolasco, R. (2021). The Bikol Agtas. Retrieved from https://ncca.gov.ph/about-ncca3 /subcommissions/subcommission-on-cultural-communities-and-traditional-arts-sccta/centralcultural-communities/the-bikol-agtas/

Peterson, N. (2016). What is the policy significance of the hybrid economy?. Engaging Indigenous Economy: Debating Diverse Approaches. doi: 10.22459/caepr35.04.2016.05

Purchasing power and the Consumer Price Index (CPI). (2018). Retrieved from https://learn.saylor.org/mod/page/view.php?id=8865 
Sanders, W. (2016). Engaging Indigenous Economy. Canberra: ANU Press.

Segal, H. (2019). Finding a Better Way: A Basic Income Pilot Project for Ontario. Retrieved from https://www.ontario.ca/page/finding-better-way-basic-income-pilot-project-ontario

STEM learning (2016). The importance of food security and how it can be brought into the classroom | STEM. Retrieved from https://www.stem.org.uk/news-and-views/news/importancefood-security-and-how-it-can-be-brought-classroom

The 1987 Constitution of The Republic of The Philippines - Article XIII. Retrieved from https://www.officialgazette.gov.ph/constitutions/the-1987-constitution-of-the-republic-of-thephilippines/the-1987-constitution-of-the-republic-of-the-philippines-article-xiii/

Toppr. What are Economic Activities? Retrieved from https://www.toppr.com/guides/commercial-knowledge/business-and-commercialknowledge/what-are-economic-activities/

Torres, L. (2016). Indigenous Peoples in the Philippines: Perspective on Inclusion. Retrieved from http://www.globi-observatory.org/indigenous-peoples-in-the-philippines-perspectives-oninclusion/

United Nations (2007). United Nations Declaration on the Rights of Indigenous People (UNDRIP). Retrieved from https://www.un.org/development/desa/indigenouspeoples/wpcontent/uploads/sites/19/2018/11/UNDRIP_E_web.pdf

United Nations (2016) . Gender and indigenous peoples. Retrieved from https://www.un.org/esa/socdev/documents/BriefingNote2_GREY.pdf 